\title{
Motivação de equipes em unidades de informação
}

\author{
Vanessa Lima dos Santos \\ Daniela Pereira dos Reis de Almeida \\ Marta Lígia Pomim Valentim \\ Universidade Estadual Paulista - Brasil
}

ANÁLISE / ANALYSIS

\section{Resumo}

Este artigo, por meio de uma revisão de literatura nas áreas de Ciência da Informação e Administração, buscou resgatar o referencial teórico sobre liderança, motivação, trabalho em equipe, competências, habilidades e atitudes do líder. Além disso, foi elaborado um estudo exploratório junto a diretores/gestores de bibliotecas universitárias. A partir da análise da literatura selecionada e da pesquisa exploratória, infere-se que o líder que atua em unidades de informação (Uls) pode desenvolver algumas ações que possibilitem motivar a equipe, a qual lidera, como por exemplo: implantar programas participativos; estabelecer metas desafiadoras; incentivar trabalhos em grupo; promover rotatividade de cargos e funções; criar sistemas de divulgação de resultados; estimular a criatividade; promover um bom ambiente de trabalho; promover educação e treinamento individual/grupo; definir claramente as responsabilidades; delegar autoridade conscientemente, cobrar resultados; entre tantas outras. Dessa maneira, entende-se que o líder que atua em unidades de informação necessita conhecer os fatores que possibilitam a motivação da equipe. Para tanto, é preciso observar as aspirações de seus colaboradores e verificar se a organização tem sido capaz de satisfazê-las. Assim, cabe ao profissional da informação capacitar-se para desempenhar bem essa função.

Palavras-chave

Profissional da informação; Competências; Habilidades; Motivação; Equipes bibliotecárias; Liderança; Unidades de informação

\section{Teams motivation in units of information}

\begin{abstract}
This article, through the revision of literature in the areas of Information Science and Administration, sought to rescue the theoretical yardstick about leadership, motivation, team works, competences, abilities and attitudes of leader. Beyond that was elaborated an exploratory study with directors/managers of university libraries. From the analysis of literature selected and the exploratory research, infers that the leader which works in units of information can develop some actions that are going to motivate the team, to which leads, as by example: implant participatory programs; establish challenging goals; encourage works in group; promote turnaround of post and functions; create results disclosure systems; stimulate the creativity; promote a good environment at work; promote education and training individual/group; defined clearly the responsibilities; delegate authority consciously, charge results; and others possibilities. In this manner, understands that leader that works in units of information is going to know the factors that enable the motivation of the team. For so much, it is necessary observe the aspirations of his collaborators and verify if organization has been capable of satisfy them. In that sense, falls to the informational professional qualify itself for perform that function.
\end{abstract}

Keywords

Competences; Abilities; Information professional; Motivation; Library Teams; Leadership; Units of Information 


\section{Introdução}

Nos prenúncios da Segunda Guerra Mundial ocorreu uma notável mudança na Administração, ressaltando o caráter democrático da gestão organizacional, deslocou-se a ênfase na estrutura e nas tarefas para a ênfase nas pessoas, nos grupos e na organização informal (CHIAVENATO, 2000, p.107). Surgia assim, nos Estados Unidos, a Teoria das Relações Humanas (TRH). Esta Teoria, apoiada em valores humanísticos, nasceu para equilibrar a tendência dos pressupostos formais e técnicos da Teoria Clássica da Administração, cujo perigo era a desumanização do indivíduo no ambiente organizacional. No âmbito da escola clássica as necessidades, sentimentos, atitudes, interesses e motivação das pessoas (sistemas sociais), em muitos casos, não são preocupações dos gestores. Ressalta-se apenas o fazer organizacional, sob o ponto de vista técnico, bem como as normas e procedimentos de trabalho, as atribuições dos funcionários, o bom uso dos recursos, estrutura organizacional, tecnologia etc.

A partir da Teoria das Relações Humanas uma nova forma de gerenciar é introduzida aos gestores e as pessoas que atuam em organizações, passando a predominar nos ambientes organizacionais fatores como: motivação, liderança, comunicação, organização informal, dinâmica de grupo etc. É nesse contexto que se desenvolve, a partir da década de 50, uma nova visão das teorias administrativas baseada no comportamento humano nas organizações (CHIAVENATO, 2000, p.107).

A abordagem comportamental foi influenciada diretamente pelas Ciências Comportamentais, com destaque para a Psicologia Organizacional. As Ciências do Comportamento conduziram a um "olhar" e a uma nova direção, no âmbito das teorias administrativas: a ênfase permanece nas pessoas, na natureza e nas características do ser humano. Estuda-se a motivação humana (necessidades básicas) definindo estilos de gestão, caracterizando as organizações como sistemas sociais cooperativos e como sistemas de decisão.

Maximiano (2000a, p.243) discute o enfoque comportamental e destaca dois objetivos básicos desta Teoria: compreender os sistemas sociais que compõem as organizações; entender os mecanismos e as características que individualizam e influenciam o comportamento das pessoas. Pode-se, ainda, verificar um outro objetivo implícito nas perspectivas comportamentais que é o de propiciar instrumentos que auxiliem a gestão, tendo por base 0 conhecimento sobre o comportamento das pessoas, como indivíduos e membros de grupos.

A motivação nasce da interação entre sujeito e meio ambiente. Quando não há motivação é muito difícil conquistar objetivos e metas que se quer atingir. Motivar significa agir sobre os distintos níveis da conduta humana, ou seja, é um movimento voltado aos fenômenos sociais humanos (DIAS; DIAS, 2006, p.13). Sendo assim, tanto a motivação quanto a liderança/líder terão papéis de destaque no decorrer deste trabalho.

Devido à importância dada ao comportamento humano e a motivação nos espaços corporativos, objetiva verificar se os bibliotecários participantes da pesquisa possuem competências e habilidades que contribuam para a motivação da equipe que gerenciam. Outro aspecto relevante refere-se a conhecer as necessidades de formação acadêmica para motivar equipes em unidades de informação (UIs). Além disso, apresenta um quadro comparativo desses aspectos, a partir da análise dos dados coletados entre as equipes das unidades de informação pesquisadas.

\section{Competências, habilidades e atitudes}

Dada a relevância dos termos 'competência', 'habilidade' e 'atitude', faz-se necessário conceituá-las. A partir dos conceitos apresentados, acredita-se que as discussões desenvolvidas neste artigo serão mais bem compreendidas. Além disso, é importante mencionar que as pessoas atuam em equipe, portanto, os ambientes organizacionais possuem líderes ou liderados, o que torna tão importante o estudo do comportamento humano nas organizações.

Nos últimos anos diversos autores têm debatido com maior freqüência sobre o que é competência. No entanto, esse não é um conceito novo, desde a Idade Média já se abordava esse conceito competência. $\mathrm{Na}$ área de Ciência da Informação esse tema tem tido grande destaque, mais especificamente sobre as competências que os profissionais precisam ter para desempenhar suas funções ou, ainda, sobre as competências que usuários precisam ter para apreensão das informações essenciais às suas necessidades informacionais.

Uma das definições mais utilizadas na área de Ciência da Informação, foi retirada do IV Encuentro de Escuelas de Bibliotecología y Ciencia de la Información del Mercosur: 
Por competências profissionais se entende o conjunto de habilidades, destreza, atitudes e conhecimentos teórico-práticos necessários para cumprir uma função especializada de modo socialmente reconhecível e aceitável (VALENTIM, 2000, p.17).

Neste evento, realizado em Montevidéu, em 2000, também foram definidas várias competências específicas para os profissionais da informação: "1) Competências em Comunicação e Expressão; 2) Competências Técnico-Científicas; 3) Competências Gerenciais; e 4) Competências Sociais e Políticas”. Destacam-se as competências gerenciais e as sociais e políticas, porquanto incluem a necessidade de uma formação acadêmica que inclua as questões de liderança e motivação:

- $\quad$ Dirigir, administrar, organizar e coordenar unidades, sistemas e serviços de informação;

- Aplicar técnicas de marketing, liderança e de relações públicas [esta competência também está presente dentre as competências relacionadas à Comunicação e Expressão];

- Assessorar no planejamento de recursos econômico-financeiros e humanos do setor;

- Promover uma atitude crítica e criativa a respeito das resoluções de problemas e questões de informação;

- Fomentar uma atitude aberta e interativa com os diversos atores sociais (políticos, empresários, educadores, trabalhadores e profissionais de outras áreas, instituições e cidadãos em geral) (VALENTIM, 2000, p.20).

Moreiro González e Tejada (2004, p.100, tradução nossa) afirmam que as competências-chave para o profissional da informação são:

Organizar; Antecipar-se; Analisar uma situação; Ser rigoroso; Realizar uma síntese, resumo; Ouvir; Ser preciso; Ser disponível; Negociar; Adaptar-se; Ensinar; Trabalhar em equipe; Autoformar-se; Conduzir uma equipe; Ter espírito crítico; Ser autônomo; Motivar-se; Avaliar-se.

Para Maximiano (2004, p.273) "As competências influenciam os interesses, as escolhas e, conseqüentemente, o desempenho [...] a direção, a intensidade e [por outro lado] a permanência da motivação são determinadas pelas competências".

O Conselho da Justiça Federal (CJF) (s.d., p.2) define competências comportamentais como sendo o "conjunto de conhecimentos, habilidades e atitudes que geram resultados para a organização e agregam valor à pessoa [...]". É por meio do processo de aprendizagem que se desenvolvem as competências comportamentais, conseqüentemente, a instituição adquire novas competências ou mantêm as existentes.

Em relação às habilidades Maximiano (2000, p.76) explica que "[...] são essenciais para o desempenho de tarefas, são aptidões que se desenvolveram. O desempenho de qualquer papel gerencial depende da posse e aprimoramento de habilidades" específicas.

Mintzberg (1986 apud MAXIMINIANO, 2000a, p.78) identifica e categoriza oito habilidades essenciais: 1. relacionamento com os colegas; 2. liderança; 3. resolução de conflitos; 4. processamento de informações; 5. tomar decisões em condições de ambigüidade; 6. alocar recursos; 7. empreendedorismo; 8. introspecção.

Santos (2000, p.115) afirma que "as habilidades e conhecimentos para o desempenho das tarefas gerenciais nos sistemas de informação são e serão, cada vez mais, necessárias”, ou seja, há a necessidade de uma formação acadêmica que contemple esses conteúdos formadores em seus currículos.

Através da literatura pode-se, ainda, acrescentar outras habilidades: habilidade intelectual e técnicas (específicas), planejar tarefas, ser interativo, polivalente, curioso, saber administrar e liderar pessoas, ter automotivação, personalidade firme, senso de compromisso, estilo participativo, adaptabilidade social, excelência na comunicação oral e escrita entre outras (MARCHIORI, 1996; BERTO; PLONSKI, 1999; PONJUÁN DANTE, 2000; NEVES, 2002).

Observa-se que há uma proximidade entre os termos 'habilidade' e 'aptidão'. Para esclarecer essa questão, realizarse-á uma breve explicação. Aptidão refere-se à capacidade para a realização de tarefas ou atividades, ou seja, são habilidades em potencial. As pessoas se constituem em combinações complexas de aptidões que se desenvolvem e são usadas de maneira singular. Desde que se tenha oportunidade e motivação, uma pessoa pode transformar suas aptidões em habilidades e desenvolvê-las continuamente. O desenvolvimento de habilidades depende não apenas 
de aptidões, mas de motivação, experiência e oportunidades educacionais apropriadas (MAXIMIANO, 2004, p.281). Assim como as habilidades, às aptidões, também, se subdividem em categorias: cognitivas ou intelectuais; físicas; estéticas; verbais; musicais; interpessoais; entre outras.

As atitudes e as aptidões são conceitos existentes nas Ciências Comportamentais que ajudam a entender as pessoas e seu comportamento. Maximiano (2000b, p.356) afirma que as atitudes são características pessoais que emprestam significado a diferentes estímulos e se traduzem em opiniões e escolhas.

Valentim (2002, p.126) apresenta a proposta das Diretrizes Curriculares para a área de Ciência da Informação, formuladas pelo Ministério de Educação (MEC) brasileiro, no que tange as atitudes profissionais:

- Sensibilidade para a necessidade informacional de usuários reais e potenciais;

- Flexibilidade e capacidade de adaptação;

- Curiosidade intelectual e postura investigativa para continuar aprendendo;

- Criatividade;

- Senso crítico;

- $\quad$ Rigor e precisão;

- Capacidade de trabalhar em equipes profissionais;

- Respeito à ética e aos aspectos legais da profissão;

- Espírito associativo.

Em relação à postura do profissional da informação líder, as atitudes descritas anteriormente muito têm a contribuir com a rotina organizacional, com o processo decisório, bem como com o desenvolvimento e manutenção da motivação e do espírito de equipe.

Uma das atuações desejáveis definidas pelas organizações signatárias da Resolución de Tokyo (1994, p.314) refere-se a assegurar que os profissionais da informação, por meio da educação continuada, mantenham e desenvolvam suas capacidades e atitudes, para fazer frente às mudanças. É preciso que as equipes de trabalho sejam capazes de acompanhar essas mudanças.

\section{Motivação}

A palavra motivação deriva, originalmente, das palavras latinas motivus, movere, que significa mover. Indica 0 processo pelo qual um conjunto de razões ou motivos explica, induz, incentiva, estimula ou provoca algum tipo de ação no comportamento humano (MAXIMIANO, 2000b, p.347). Motivo, motor e emoção são outras palavras que têm a mesma raiz.

Alguns autores entendem motivação como um processo, de forma que há no ambiente organizacional há necessidade de se criar mecanismos de motivação constantemente, conforme explicam Megginson, Mosley e Pietri Jr. (1998, p.346) "Motivação é um processo de induzir uma pessoa ou um grupo, cada qual com necessidades e personalidades distintas, a atingir os objetivos da organização, enquanto tenta atingir os objetivos pessoais".

$\mathrm{Na}$ literatura existem muitos conceitos sobre motivação. Para Maximiano (2004, p.266) motivação é "um processo fundamental do comportamento que afeta o desempenho das pessoas e das organizações". Gooch e McDowell (1988, p.51) entendem a motivação como uma força que se encontra no interior do indivíduo, contudo, relacionada a um desejo, de forma que uma pessoa jamais poderá motivar outra, somente terá meios de estimulá-la. Bergamini (1991, p.38), também, compartilha dessa mesma opinião, pois, afirma que a motivação é "um impulso, uma força propulsora que leva o indivíduo a satisfazer suas necessidades, desejos e emoções".

As definições apresentadas sobre motivação levam em conta os desejos e as necessidades intrínsecas de cada pessoa. Desse modo, ressalta-se que a motivação humana depende da intensidade dos motivos, sejam internos ou externos. Os motivos internos são aqueles que surgem no interior do indivíduo, conforme já mencionado 
anteriormente: necessidades, aptidões, habilidades, atitudes, interesses e valores, que torna o indivíduo capaz de realizar determinadas ações/tarefas e não outras. Os motivos externos são aqueles criados pela situação ou ambiente em que o indivíduo se encontra: estímulos e incentivos que o ambiente oferece ou objetivos que a pessoa persegue ou quer atingir (MAXIMIANO, 2000b, p.357).

Nesse sentido, defende-se que os profissionais da informação necessitam conhecer melhor os aspectos relacionados à motivação humana, porquanto propiciarão ao profissional da informação líder as condições necessárias para perceber as causas do estado de disposição das pessoas para a realização de ações/tarefas nas unidades de informação em que atuam.

\subsection{Teorias motivacionais}

Apresentar-se-á, de forma resumida, os conceitos das principais teorias sobre motivação, que explicam o desempenho das pessoas em distintas situações de trabalho. Entretanto, será dada ênfase as teorias de processo, por abordarem os fatores internos que levam as pessoas a se motivarem.

Maximiano (2004, p.297), propõe a divisão das teorias motivacionais em dois grupos: as teorias de processo (procura explicar como funcionam os mecanismos da motivação) e as teorias de conteúdo (procura explicar quais são os motivos específicos que fazem as pessoas agirem).

Sobre as teorias motivacionais, Bergamini (1991, p.25) também destaca dois grupos: o primeiro ressalta que a força que conduz o comportamento motivado está fora da pessoa, ou seja, nasce de fatores extrínsecos que são, de certa forma, soberanos à vontade do indivíduo. Preocupa-se, também, em inventariar as necessidades individuais que são comuns a todas as pessoas. O segundo grupo ressalta que as ações humanas são espontâneas e gratuitas, uma vez que têm suas origens em impulsos interiores e, assim, o próprio ser humano traz em si o potencial e a fonte de origem de seu comportamento motivacional.

Embora se reconheça que o indivíduo pode agir movido por agentes externos ou impulsionado por suas forças interiores, não se pode confundir esses dois tipos de comportamento, uma vez que eles são qualitativamente distintos e, por isso, merecem explicações diferentes (BERGAMINI, 1990, p.25). Dessa forma, existe uma multiplicidade de teorias e hipóteses que se acumularam nas últimas décadas, gerando interpretações e modelos mais variados quanto à compreensão da motivação.

Com o objetivo de apresentar as principais teorias motivacionais resumidamente, buscou-se na obra de Maximiano (2002) as principais características das teorias motivacionais, que serão apresentadas a seguir.

\subsection{Teorias de processo}

As teorias de processo objetivam explicar como funcionam os mecanismos da motivação que levam os seres humanos a terem comportamentos distintos, pois nem sempre as pessoas fazem as mesmas coisas pelos mesmos motivos. As teorias de processo abrangem as seguintes teorias: Modelo Comportamental, Teoria da Expectativa, Behaviorismo e Teoria da Equidade.

\subsubsection{Modelo comportamental}

O modelo comportamental explica como os motivos determinam o comportamento e as ações individuais. Este modelo baseia-se em algumas premissas: todo comportamento é motivado; o comportamento é orientado para realização de algum objetivo; o comportamento que procura realizar algum objetivo pode ser influenciado por conflito, frustração ou ansiedade. Engloba os termos: comportamento, motivação e objetivo (ansiedade, conflito, frustração). 
Apresenta-se o conceito de comportamento como sendo qualquer ação ou manifestação observável das competências e características individuais. Ex: opinar, decidir, pensar. Esse modelo baseia-se na idéia de que todo comportamento é acionado por algum tipo de estímulo, seja ele interno ou externo.

Em relação ao conceito de motivação, explica-se como sendo um comportamento constantemente motivado por estímulos internos (do próprio indivíduo) ou externos (do ambiente).

Quanto ao conceito de objetivo, menciona-se que é o resultado que se procura alcançar, entretanto essa realização pode ser impedida por: ansiedade, conflito e/ou frustração.

Neste modelo, acredita-se que o comportamento das pessoas é similar e que os mecanismos que as regem têm os mesmos fundamentos. Contudo, o que difere uma pessoa da outra são as diferenças individuais, influenciadas pelas variáveis do ambiente, cuja dinâmica modifica os motivos e os objetivos tornando-os mais ou menos significativos para cada indivíduo.

\subsubsection{Teoria da expectativa}

Defende que as pessoas se esforcem para alcançar resultados ou recompensas, ao mesmo tempo em que evitam os maus resultados. Essa Teoria procura explicar a cadeia de causas e efeitos que ligam o esforço inicial ao resultado ou recompensa final. Retrata a idéia intuitiva de que o esforço depende do resultado que se deseja alcançar. Em geral, as pessoas são motivadas pela crença de que seus esforços produzem o desempenho necessário para alcançar os resultados desejados. Para a Teoria da Expectativa a motivação é vinculada à crença de que é possível alcançar um resultado, multiplicado pelo valor atribuído ao resultado, ou seja, a motivação (M) é igual ao valor atribuído a um objetivo (V), versus a expectativa de alcançar esse mesmo objetivo.

\subsubsection{Behaviorismo/Comportamentalistas}

É uma área controversa do enfoque comportamental, dada a sua associação com o adestramento de animais. No entanto, aborda conceitos importantes que deveriam ser do conhecimento dos gestores de unidades de informação. Essa teoria baseia-se nas concepções de pesquisadores como Ivan Petrovich Pavlov, Edward C. Tolman, Burrhus F. Skinner, entre outros, que afirmam que o comportamento é reforçado por suas próprias conseqüências (estímulos de reforços). No entendimento dos behavioristas a aprendizagem se dá a partir da prática, cuja dinâmica influi no comportamento do indivíduo.

\subsubsection{Teoria da Eqüidade}

A principal premissa desta Teoria é a crença de que as recompensas devem ser proporcionais ao esforço e iguais para todos, havendo eqüidade e equilíbrio. Assim, ajuda a entender a reação das pessoas à distribuição das recompensas no grupo de trabalho e sua influência sobre a motivação.

\subsection{Teorias de Conteúdo}

Procuram explicar quais motivos ou estímulos agem sobre as pessoas para ativar seu comportamento. As primeiras hipóteses sobre o conteúdo da motivação foram propostas pelos filósofos gregos, nas discussões sobre o conceito de felicidade. 


\begin{tabular}{|l|l|}
\hline $\begin{array}{l}\text { Homem } \\
\text { econômico- } \\
\text { racional }\end{array}$ & $\begin{array}{l}\text { A motivação encontra-se na perspectiva do ganho. O motivo importante } \\
\text { é ter bens materiais (Administração Científica). }\end{array}$ \\
\hline Homem social & $\begin{array}{l}\text { A motivação é o grupo. Os motivos importantes são o reconhecimento } \\
\text { e aceitação pelos colegas (Teoria das Relações Humanas). }\end{array}$ \\
\hline $\begin{array}{l}\text { Homem auto- } \\
\text { realizador }\end{array}$ & $\begin{array}{l}\text { A motivação é a realização interior. O que importa e motiva é a } \\
\text { satisfação íntima (Teoria Comportamental / Teorias de Processo). }\end{array}$ \\
\hline Homem complexo & $\begin{array}{l}\text { A motivação não tem causa única. Diversos motivos ou causas são } \\
\text { importantes para mover o comportamento. }\end{array}$ \\
\hline
\end{tabular}

Figura 1: Motivação Humana nas Teorias da Administração.

Fonte: Maximiano - 2002 - p. 285.

\subsubsection{Teoria das necessidades}

Essa teoria propõe que as pessoas são motivadas pelas necessidades humanas, ou seja, quando satisfeita uma necessidade, cessam-se os estímulos que movimentam o comportamento. Abraham Maslow, autor dessa teoria, dedicou-se na busca da compreensão do comportamento humano e desenvolveu a idéia de que as necessidades humanas estão organizadas e dispostas em níveis, mais especificamente, numa hierarquia complexa. Para Maslow (2002, p.288), as necessidades dividem-se em cinco grupos:

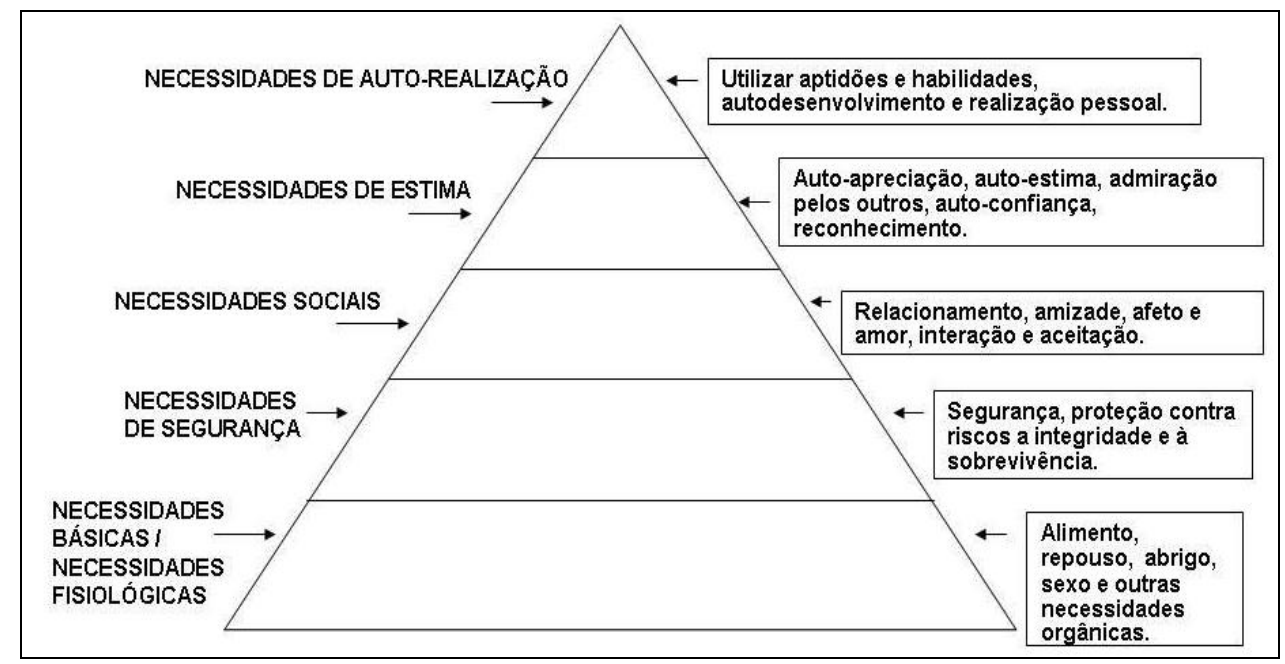

Figura 2: Necessidades Humanas - Maslow.

Fonte: Maximiano - 2002 - p. 288.

A motivação humana, portanto, está relacionada ao atendimento das distintas necessidades e, uma vez suprida, volta-se para outra necessidade, ainda, não satisfeita e, assim, sucessivamente, em um processo contínuo. Contudo, ressalta-se que não são todas as pessoas que necessitam satisfazer o último nível (auto-realização), ou seja, as necessidades dependem do contexto interno e externo ao indivíduo. 


\subsubsection{Teoria da existência, relacionamento e crescimento (ERC)}

Clayton Alderfer, autor dessa Teoria (1969), propõe uma versão revista da Teoria das Necessidades de Maslow, e a denomina de Teoria ERG, originada pelas palavras da língua inglesa 'Existence, Relatedness and Growth'. As palavras correspondentes em português são 'Existência, Relacionamento e Crescimento' formando a sigla ERC.

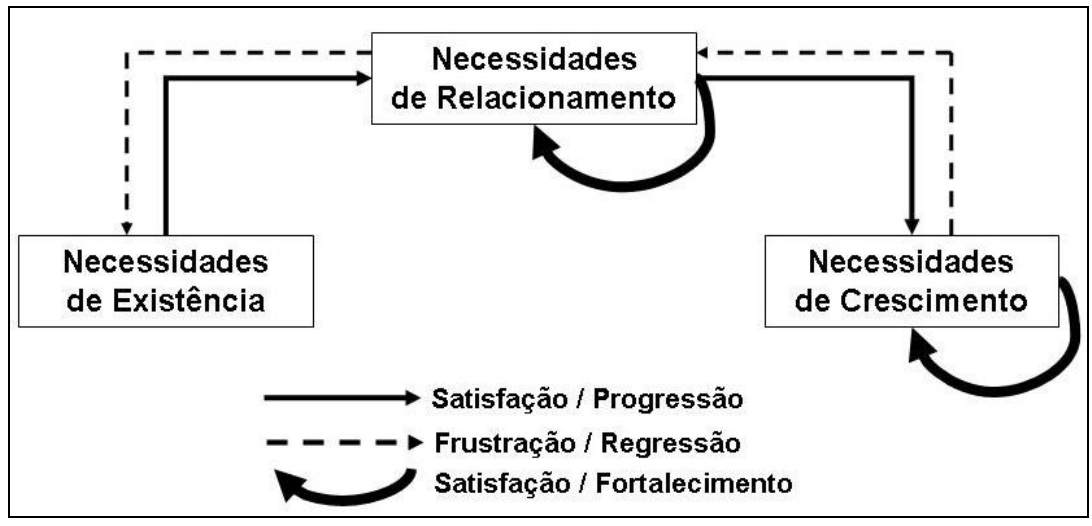

Figura 3: Necessidades Humanas - Alderfer. Fonte Adaptada: http://www.12manage.com

As teorias de Maslow e Alderfer se diferem, visto que Alderfer acredita que a satisfação das necessidades humanas não obedece a uma hierarquia, mas sim ocorre simultaneamente. No entanto, uma teoria não contradiz a outra, mas se complementam. Alderfer soma à Teoria de Maslow mais dois princípios: o primeiro compreende que mais de uma necessidade pode funcionar ao mesmo tempo, o segundo compreende que se uma necessidade do topo da pirâmide permanecer insatisfeita aumenta o desejo de se satisfazer uma necessidade da base.

\subsubsection{Teoria de McClelland}

David McClelland é o idealizador desta Teoria (1961), cujo estudo identificou três motivos ou necessidades específicas que, também, se somam a Teoria das Necessidades de Maslow.

\begin{tabular}{|l|c|l|}
\hline \multicolumn{1}{|c|}{ CONCEITO } & SíMBOLO & \multicolumn{1}{|c|}{ DEFINIÇÃO } \\
\hline $\begin{array}{l}\text { Necessidades de realização } \\
\text { (Need for achievement) }\end{array}$ & n-ach & $\begin{array}{l}\text { Necessidade de sucesso, êxito competitivo, } \\
\text { avaliado segundo um padrão pessoal de } \\
\text { excelência. }\end{array}$ \\
\hline $\begin{array}{l}\text { Necessidades de autoridade } \\
\text { e poder (Need for authority } \\
\text { and power) }\end{array}$ & N-pow & $\begin{array}{l}\text { Necessidade de controlar ou influenciar direta } \\
\text { ou indiretamente outras pessoas. }\end{array}$ \\
\hline $\begin{array}{l}\text { Necessidades de afiliação } \\
\text { (Need for affiliation) }\end{array}$ & n-affil & $\begin{array}{l}\text { Necessidade de relacionamento e amizade } \\
\text { com outros indivíduos. }\end{array}$ \\
\hline
\end{tabular}

Figura 4: Necessidades Humanas - McClelland.

Fonte: Maximiano - 2002 - p.290. 
No âmbito das necessidades de realização, o indivíduo possui uma forte tendência à realimentação e progresso. Quanto às necessidades de autoridade e poder, o indivíduo possui uma forte tendência a querer ser influente, e de que suas idéias prevaleçam, além da necessidade de reconhecimento e prestígio. Por último, no que tange às necessidades de afiliação, há a busca de relacionamentos amigáveis e de interação com outras pessoas.

\subsubsection{Teoria X e Teoria Y}

Douglas McGregor, autor da Teoria X e Teoria Y (1960), apresenta duas formas recorrentes de se gerenciar o comportamento humano: a primeira, a Teoria $X$ é conservadora e considera as pessoas apenas como recursos ou meios de produção; a segunda, a Teoria $Y$ é vanguardista e considera as pessoas como elementos essenciais para a organização. As duas Teorias são opostas, visto que uma privilegia o controle das pessoas e a outra privilegia a criatividade e a participação das pessoas que atuam em uma organização.

\subsubsection{Teoria dos Dois Fatores}

Frederick Herzberg, autor da Teoria dos Dois Fatores (1959), estudou de que forma o comportamento das pessoas, o ambiente de trabalho e o desenvolvimento das atividades cotidianas interagem para produzir a motivação humana. De acordo com esta Teoria, a motivação resulta de fatores que influenciam no desempenho humano. Para Herzberg existem dois fatores fundamentais: os fatores higiênicos ou fatores extrínsecos e os fatores motivacionais ou fatores intrínsecos.

Os fatores extrínsecos criam o clima psicológico e material saudável e influenciam a satisfação, cujas condições são absorvidas no local em que o trabalho é realizado. Esses fatores estão fora do controle das pessoas, são fatores de contexto e se situam no ambiente externo aos indivíduos.

Os fatores intrínsecos estão sob o controle dos indivíduos, pelo fato de que se relacionam com o que as pessoas fazem ou desempenham. Somente as condições ambientais não são suficientes para produzir motivação para o trabalho. Para que haja motivação, segundo Herzberg, é preciso que os indivíduos interajam com o trabalho, que visualizem nele a possibilidade de exercitar suas habilidades e desenvolver suas aptidões. A Teoria dos Dois Fatores defende que a motivação pelo trabalho é diferente da satisfação com o ambiente de trabalho. $\mathrm{O}$ trabalho em si atende a necessidades e produz satisfações diferentes das que estão associadas ao ambiente ou às condições de trabalho.

\section{Motivação de equipes}

Antes de abordar diretamente o assunto 'motivação de equipes' é necessário apresentar, mesmo que de forma sucinta, aspectos relevantes sobre clima organizacional, porquanto certamente afetará a motivação das equipes nos ambientes informacionais, bem como nas organizações em geral.

Tachizawa, Ferreira e Fortuna (2004, p.239) entendem por clima organizacional "a qualidade ou a propriedade do ambiente institucional que é percebida ou experimentada pelos membros da organização" e, que obviamente, influencia o comportamento das pessoas.

Os princípios do trabalho em equipe incluem elementos básicos do comportamento humano e os processos aparentam ser enganosamente simples, contudo, são complexos e, por isso mesmo, o êxito de uma equipe depende essencialmente do conhecimento sobre as necessidades, crenças, valores, desejos, entre outras, de cada indivíduo que a compõe, não sendo possível a abordagem do trabalho em grupo sem uma análise do comportamento humano, sem um estudo sobre o que motiva e capacita um indivíduo a aceitar ser participante e se envolver com uma equipe de qualquer natureza (CARDOZO, 2003, p.5). 


\subsection{Trabalho em equipe}

Maximiano (2004, p.326) define 'desenvolvimento de equipes' como um processo para aprimorar as competências de seus integrantes, com a finalidade de torná-los uma equipe de alto desempenho. $O$ autor afirma, também, que esse é um processo contínuo, visto que há a necessidade de desenvolver, constantemente, estratégias para o desenvolvimento de equipes. Dentre as estratégias que podem contribuir para o desenvolvimento de equipes, destaca-se: saber ouvir e falar; definir objetivos claros para o grupo; organizar o grupo de forma coerente; propiciar desafios para o grupo; promover a troca de conhecimento; criar identidade para o grupo; instituir normas organizacionais de avaliação e desempenho; estabelecer processos seletivos claros; oferecer treinamento continuado; oferecer recompensas pelo desempenho; propiciar um clima de abertura intelectual e crítica; ter pensamento grupal.

É fundamental para um líder saber desenvolver uma equipe, pois "a maior parte das atividades humanas é realizada por equipes, não por indivíduos. Os resultados do administrador são os resultados das unidades organizacionais sob sua supervisão direta ou influência" (MAXIAMIANO, 2000a, p.71).

Uma equipe tem como essência a colaboração mútua e integrada. A palavra colaboração é derivada do latim cum laborare, e significa "trabalhar junto". A palavra-chave que melhor define colaboração é 'junto', entretanto, ela por si só não define equipe, visto que uma equipe não é apenas um grupo que trabalha em conjunto. Conselhos, comitês, comissões e forças tarefas não são, necessariamente, uma equipe. $O$ trabalho em equipe proporciona um contexto compartilhado e de cooperação, de forma que as pessoas são capazes de interagir umas com as outras, assim, os membros das equipes desenvolvem novos pontos de vista, por meio de diálogo e discussão (NONAKA, 2000, p.48).

A eficácia de uma equipe é determinada pela capacidade de cada pessoa que a compõe, das metas claramente definidas e do comprometimento dos membros para alcançá-las. Desse modo, os membros de uma determinada equipe recebem um significativo retorno e aprendem a conviver com a própria diversidade, bem como passam a entender as forças e fraquezas individuais e desenvolver um entendimento comum das metas e objetivos a serem alcançados. Trabalhar em equipe não é uma tarefa simples, por isso mesmo requer algumas competências e habilidades específicas para isso.

Um problema que pode afetar uma equipe é a falta ou excesso de comando. Contudo, todas as pessoas que fazem parte da equipe devem estar acessíveis e ter liberdade para expor suas idéias e críticas, ou seja, a comunicação é a base para a realização de um bom trabalho. Segundo Katzenbach e Smith (1993 apud CARDOZO, p.19), "o trabalho em equipe sustenta um conjunto de valores relativos à pré-disposição em ouvir e responder construtivamente aos pontos de vista de outras pessoas".

Lane (1994 apud CARDOZO, p.19) explica que uma equipe se constitui por meio da "[...] relação significativa entre duas ou mais pessoas [, bem como] se processa através de ações conjuntas". Essa interação ocorre em função das necessidades materiais e/ou psicossociais e visa à produção de suas satisfações. Dessa forma, a essência de uma equipe é a colaboração mútua, o compromisso comum, a cooperação e integração. Sem isso, as pessoas que compõem um determinado grupo desempenham suas atividades de forma individual.

Easton (1993 apud CARDOZO, p.19) define equipe como sendo "um grupo de trabalhadores que conjuntamente compartilham um objetivo e possuem a habilidade de monitorar seu próprio desempenho através de um feed-back contínuo". Entretanto, cada participante ativo de uma equipe sabe de que forma poderá afetar o alcance dos objetivos, isto é, uma equipe entrosada, com metas bem definidas, têm capacidade suficiente para atingir seus objetivos sem que haja uma presença constante de supervisão.

A maturidade é fundamental para o trabalho em equipe, uma vez que exige em algumas situações a decisão de abrir mão da própria opinião em favor de outra e, muitas vezes, aceitar que existem opiniões mais coesas do que a opinião que defendia. Nesse sentido, controlar as emoções é importante, visto que todas as pessoas de uma equipe têm algo a contribuir, ou seja, ninguém é 'dono da verdade'. (FELLIPE, 2009). O trabalho em equipe vai exigir de seus membros características comuns a qualquer grupo que queira alcançar bons resultados, como por exemplo, estar aberto a desafios, coesão, comprometimento, responsabilidade e motivação. 
A motivação de equipes visa a manter seus integrantes constantemente mobilizados para a realização dos objetivos coletivos, por meio de estratégias baseadas nas teorias comportamentais. A motivação de equipes traz benefícios a qualquer tipo de organização, bem como ajuda a manter o clima organizacional coeso.

Segundo Caudron (1997, p.83) "não existe uma fórmula mágica para conquistar (ou reconquistar) a boa vontade dos funcionários - o mais sensato é combinar uma série de atitudes tão essenciais quanto os princípios que norteiam o comportamento humano". Cardozo (2003, p.57) indica os principais fatores motivadores de um indivíduo enquanto participantes de uma equipe: propósito claro e comum; colaboração e interdependência; normas claras e respeitadas; responsabilidade e empowerment; liderança; envolvimento emocional; empenho da organização; desafio; caráter.

Muitos são os fatores que resultam no sucesso ou no fracasso de uma equipe. O sucesso de uma equipe e a relação com o nível de motivação de seus membros são intrinsecamente relacionados, ou seja, uma equipe dificilmente obterá sucesso se seus membros não estiverem comprometidos com os objetivos e resultados individuais e coletivos que poderão ser alcançados. As necessidades por subsistência, segurança, reconhecimento, crescimento, entre outras, tornam-se poderosos dirigentes do comportamento humano (CARDOZO, 2003, p.26).

Hoeckele (s.d, p.1-2) destaca outros princípios básicos que podem auxiliar na motivação das pessoas que compõem equipes: fazer o que gosta, relação justa, valorização das pessoas, respeito mútuo, treinamento constante, incentivo a criatividade, crescimento pessoal e em equipe, liderança natural.

\section{Bibliotecários como líderes motivadores}

Desenvolveu-se uma pesquisa exploratória, visando a conhecer a realidade de bibliotecários que atuam na gestão de equipes. Para isso, foram entrevistados diretores de quatro bibliotecas universitárias, sendo duas unidades de informação situadas na capital e duas situadas no interior do Estado de São Paulo. Com o intuito de preservar o anonimato das pessoas entrevistadas, as bibliotecas e as pessoas que participaram da pesquisa não são identificadas.

A pesquisa de campo buscou conhecer de que forma o bibliotecário responsável atua junto à sua equipe, mais especificamente, quais são os aspectos motivacionais utilizados para a gestão da equipe, uma vez que, geralmente, o bibliotecário possui pouca formação gerencial, isto é, são poucas as disciplinas ministradas nos Cursos de Biblioteconomia do país, em que esses conteúdos são tratados com maior profundidade. Ressalta-se que muitos bibliotecários, após a conclusão do curso, atuam exclusivamente com atividades de gestão, visto que são responsáveis por unidades de informação e, conseqüentemente, pelas pessoas que atuam nessas unidades de trabalho.

Identificou-se que a média de tempo, na qual os quatro diretores/gestores atuam em suas respectivas instituições, é de onze anos e meio propiciando, assim, um maior entrosamento entre eles e suas equipes.

O fato dos diretores/gestores pesquisados possuirem bastante experiência na função, demonstra que as organizações em que atuam são estáveis e, portanto, propiciam à eles exercerem a função de direção de forma estável. Também observou-se que os sujeitos pesquisados gerenciam uma média de 22 funcionários por Unidade de Informação.

Verificou-se que a maioria dos entrevistados, durante o curso de graduação em Biblioteconomia, recebeu conteúdos formadores relacionados à área de Administração. Somente um dos sujeitos pesquisados ressaltou que na época em que cursou Biblioteconomia não havia conteúdos da área de Administração, ou seja, este sujeito respondente não recebeu conteúdos formadores vinculados à gestão de pessoas e de recursos (financeiros e de infra-estrutura).

Apenas dois sujeitos pesquisados informaram que receberam conteúdos formadores específicos voltados ao comportamento humano, sendo que um dos sujeitos destacou ter recebido conteúdos formadores sobre motivação. Contudo, ressaltou que era um dos tópicos abordados em uma das disciplinas do curso. 


\begin{tabular}{|c|c|c|c|c|}
\hline $\begin{array}{l}\text { Sujeitos } \\
\text { Pesquisados }\end{array}$ & $\begin{array}{c}\text { Unidade de } \\
\text { Informação } \\
\text { A }\end{array}$ & $\begin{array}{c}\text { Unidade de } \\
\text { Informação } \\
\text { B }\end{array}$ & $\begin{array}{c}\text { Unidade de } \\
\text { Informação } \\
\text { C }\end{array}$ & $\begin{array}{c}\text { Unidade de } \\
\text { Informação } \\
\text { D }\end{array}$ \\
\hline $\begin{array}{l}\text { Conteúdos } \\
\text { Formadores } \\
\text { Relacionados à } \\
\text { Administração }\end{array}$ & $\begin{array}{l}\text { - Administração em } \\
\text { Unidades de } \\
\text { Informaçãa, com } \\
\text { enfoque em } \\
\text { recursos humanos } \\
\text { e psicologia do } \\
\text { comportamento. }\end{array}$ & $\begin{array}{l}\text { - Não } \\
\text { recebeu. }\end{array}$ & $\begin{array}{l}\text { Administração, } \\
\text { com alguns } \\
\text { tópicos em } \\
\text { gestão de } \\
\text { recursos } \\
\text { humanos. }\end{array}$ & $\begin{array}{l}\text { - Administração, } \\
\text { com alguns } \\
\text { tópicos voltados } \\
\text { ao } \\
\text { comportamento } \\
\text { humano. }\end{array}$ \\
\hline
\end{tabular}

Figura 5: Conteúdos Formadores Relacionados à Administração. Fonte: Elaborado pelas autoras.

Todos os sujeitos pesquisados destacaram que o aprendizado para atuar na função de direção/gestão de pessoas ocorreu por meio da experiência profissional construída dia após dia. Pode-se identificar que uma das habilidades mencionadas por Mintzberg (1986), mais especificamente a habilidade de introspecção, cujo foco é a capacidade de aprender com a própria experiência, tem ocorrido no universo bibliotecário pesquisado.

Considera-se a educação continuada um importante instrumento de atualização profissional, por esse motivo, buscou-se saber se os sujeitos pesquisados fizeram algum tipo de especialização e/ou aperfeiçoamento, com 0 intuito de melhorar a própria atuação como diretor/gestor de pessoas. Todos os sujeitos pesquisados, de alguma forma, buscaram atualizar-se. No entanto, nenhum deles fez um curso de especialização e/ou aperfeiçoamento voltado especificamente à gestão de pessoas. O sujeito pesquisado da 'Unidade de Informação A' destacou que além do aprendizado obtido por meio da rotina organizacional, também, buscou aprender por meio de literatura especializada, evidenciando assim, a importância da leitura de textos técnicos e especializados da área, quando não se tem a prática.

Os bibliotecários diretores/gestores pesquisados desconhecem a existência de um curso específico sobre direção/gestão de pessoas, especialmente voltado aos profissionais da informação. Afirmaram que, geralmente, os cursos existentes possuem uma abordagem direcionada aos profissionais atuantes em empresas privadas. Ressaltaram que a motivação nesse tipo de curso é direcionada ao lucro, ou seja, motivar para lucrar, preocupandose, em alguns casos, com o melhor desempenho possível visando o aumento do lucro da empresa, sem a preocupação com os indivíduos.

Evidencia-se que todos bibliotecários pesquisados têm como atribuições fundamentais da função de direção/gestão de pessoas, o planejamento, a coordenação e a supervisão das atividades de seus colaboradores nas unidades de informação que gerenciam. Atuam no gerenciamento de pessoas, dos recursos financeiros, de infra-estrutura e de processos desenvolvidos na unidade de informação. As atividades técnicas são realizadas por outros profissionais subordinados a eles.

Nota-se que as principais atribuições estão diretamente relacionadas à gestão da equipe, conforme demonstrado na Figura 6: 


\begin{tabular}{|c|c|c|c|c|}
\hline $\begin{array}{l}\text { Sujeitos } \\
\text { Pesquisados }\end{array}$ & $\begin{array}{c}\text { Unidade de } \\
\text { Informação } \\
\text { A }\end{array}$ & $\begin{array}{c}\text { Unidade de } \\
\text { Informação } \\
\text { B }\end{array}$ & $\begin{array}{c}\text { Unidade de } \\
\text { Informação } \\
\text { C }\end{array}$ & $\begin{array}{c}\text { Unidade de } \\
\text { Informação } \\
\text { D }\end{array}$ \\
\hline $\begin{array}{l}\text { Atribuições } \\
\text { dos } \\
\text { Bibliotecários } \\
\text { Diretores / } \\
\text { Gestores }\end{array}$ & $\begin{array}{l}\text { - Coordenação das } \\
\text { atividades da } \\
\text { biblioteca, dos } \\
\text { funcionários } \\
\text { (escala e tarefas); } \\
\text { - Solução de } \\
\text { questões de } \\
\text { usuários; } \\
\text { - Gerenciamento do } \\
\text { conteúdo do site } \\
\text { da biblioteca; } \\
\text { - Orientação aos } \\
\text { estagiários; } \\
\text { - Aquisições de } \\
\text { material; } \\
\text { - Comunicação com } \\
\text { os demais } \\
\text { departamentos. }\end{array}$ & $\begin{array}{l}\text { - Administração } \\
\text { dos recursos } \\
\text { humanos, de } \\
\text { infra-estrutura, } \\
\text { materiais e } \\
\text { financeiros; } \\
\text { - Prever } \\
\text { necessidades e } \\
\text { criar } \\
\text { mecanismos } \\
\text { para resolvê-las; } \\
\text { - Agir no plano } \\
\text { estratégico; } \\
\text { - Verificar quais } \\
\text { são as } \\
\text { tendências da } \\
\text { área; } \\
\text { - Aprender com os } \\
\text { exemplos. }\end{array}$ & $\begin{array}{l}\text { - Gerir todo o } \\
\text { funciona- } \\
\text { mento da } \\
\text { biblioteca; } \\
\text { - Planejar, } \\
\text { coordenar e } \\
\text { supervisiona } \\
\text { r todo o } \\
\text { trabalho da } \\
\text { equipe. }\end{array}$ & $\begin{array}{l}\text { - Coordenar e } \\
\text { planejar as } \\
\text { atividades; } \\
\text { - Buscar recursos } \\
\text { para a melhoria da } \\
\text { infra-estrutura; } \\
\text { - Elaborar } \\
\text { regulamentos e } \\
\text { regimentos; } \\
\text { - Criar e gerenciar } \\
\text { comissões } \\
\text { técnicas; } \\
\text { - Liderar reuniões; } \\
\text { - Responsável por } \\
\text { toda infra- } \\
\text { estrutura; } \\
\text { - Prever } \\
\text { necessidades e } \\
\text { solucionar } \\
\text { problemas; } \\
\text { - Delegar, conversar } \\
\text { / perguntar sobre o } \\
\text { trabalho, avaliar, } \\
\text { cobrar. }\end{array}$ \\
\hline
\end{tabular}

Figura 6: Atribuições dos Bibliotecários Diretores/Gestores das Uls.

Fonte: Elaborado pelas autoras.

A pesquisa de campo buscou identificar, na opinião dos bibliotecários diretores/gestores entrevistados, quais são as competências, habilidades e atitudes, que o líder necessita ter para motivar a equipe que dirigem/gerenciam. 


\begin{tabular}{|c|c|c|c|c|}
\hline $\begin{array}{l}\text { Sujeitos } \\
\text { Pesquisados }\end{array}$ & $\begin{array}{c}\text { Unidade de } \\
\text { Informação } \\
\text { A }\end{array}$ & $\begin{array}{c}\text { Unidade de } \\
\text { Informação } \\
\text { B }\end{array}$ & $\begin{array}{c}\text { Unidade de } \\
\text { Informação } \\
\text { C }\end{array}$ & $\begin{array}{c}\text { Unidade de } \\
\text { Informação } \\
\text { D }\end{array}$ \\
\hline $\begin{array}{l}\text { Competências, } \\
\text { Habilidades e } \\
\text { Atitudes do } \\
\text { Líder para } \\
\text { Motivar a Equipe }\end{array}$ & $\begin{array}{l}\text { - Conhecer a } \\
\text { atividade que é } \\
\text { desenvolvida } \\
\text { (todos os } \\
\text { processos); } \\
\text { - Bom humor; } \\
\text { - Paciência; } \\
\text { - Assumir } \\
\text { responsabilida- } \\
\text { des; } \\
\text { - Passar } \\
\text { segurança } \\
\text { para equipe; } \\
\text { - Compartilhar } \\
\text { vitórias; } \\
\text { - Dar exemplo } \\
\text { de comporta- } \\
\text { mento. }\end{array}$ & $\begin{array}{l}\text { - Pré-disposição } \\
\text { das pessoas } \\
\text { para cumprir o } \\
\text { combinado; } \\
\text { - Manter o } \\
\text { ambiente } \\
\text { harmônico; } \\
\text { - Saber trabalhar } \\
\text { em equipe; } \\
\text { - Assumir } \\
\text { responsabilidad } \\
\text { es; } \\
\text { - Ser um } \\
\text { profissional } \\
\text { dedicado; } \\
\text { - Comunicação; } \\
\text { - Engajamento, } \\
\text { comprometiment } \\
\text { o e colaboração; } \\
\text { - Confiança; } \\
\text { - Reputação. }\end{array}$ & $\begin{array}{l}\text { - Bom senso; } \\
\text { - Facilidade de } \\
\text { relacionamento; } \\
\text { - Conhecimento } \\
\text { técnico; } \\
\text { - Visão geral do } \\
\text { trabalho e da } \\
\text { instituição, isto } \\
\text { é de todo o } \\
\text { conjunto. }\end{array}$ & \begin{tabular}{|l|} 
- Paciência; \\
- Perseverança; \\
- Tato (para \\
discernir o que \\
acontece ao \\
redor); \\
- Conhecimento \\
das atividades; \\
- Não tomar \\
atitudes \\
precipitadas.
\end{tabular} \\
\hline
\end{tabular}

Figura 7: Competências, Habilidades e Atitudes do Líder. Fonte: Elaborado pelas autoras.

A partir das competências, habilidades e atitudes mencionadas pelos bibliotecários pesquisados, voltadas à direção/gestão de pessoas, foi possível elaborar uma sistematização, visando a apresentar as que mais se destacaram:

\begin{tabular}{|l|l|l|}
\hline \multicolumn{1}{|c|}{ Competências } & \multicolumn{1}{c|}{ Habilidades } & \multicolumn{1}{c|}{ Atitudes } \\
\hline - Saber trabalhar em equipe; & - Assumir responsabilidades; & - Paciência; \\
- Conhecimento técnico de & - Perseverança; & - Bom senso; \\
todos os processos e da & - Ter pulso firme, quando & - Comprometimento / \\
instituição; & necessário; & colaboração; \\
- Profissionalismo; & - Repasse das informações e & - Comportamento ético; \\
- Ser acessível; & conhecimentos. & $\begin{array}{l}\text { - Preocupação com o bem } \\
\text { - Comunicação. }\end{array}$ \\
\hline
\end{tabular}

Figura 8: Competências, Habilidades e Atitudes do Bibliotecário Diretor/Gestor. Fonte: Elaborado pelas autoras.

Pode-se considerar que as competências, habilidades ou atitudes verbalizadas pelos sujeitos são condizentes com as encontradas na literatura, visto que há uma convergência entre os autores que estudam essa questão e a realidade profissional dos bibliotecários diretores/gestores pesquisados.

Buscou-se, também, identificar junto aos entrevistados as competências, habilidades e atitudes essenciais para se atuar em uma equipe. Os sujeitos pesquisados mencionaram várias competências, habilidades e atitudes que acreditam ser fundamentais para o trabalho em equipe especificamente nas unidades de informação que dirigem/gerenciam. 


\begin{tabular}{|c|c|c|c|c|}
\hline $\begin{array}{l}\text { Sujeitos } \\
\text { Pesquisados }\end{array}$ & $\begin{array}{c}\text { Unidade de } \\
\text { Informação } \\
\text { A }\end{array}$ & $\begin{array}{c}\text { Unidade de } \\
\text { Informação } \\
\text { B }\end{array}$ & $\begin{array}{c}\text { Unidade de } \\
\text { Informação } \\
\text { C }\end{array}$ & $\begin{array}{c}\text { Unidade de } \\
\text { Informação } \\
\text { D }\end{array}$ \\
\hline $\begin{array}{l}\text { Competências, } \\
\text { Habilidades e } \\
\text { Atitudes } \\
\text { Essenciais } \\
\text { para a } \\
\text { Equipe }\end{array}$ & $\begin{array}{l}\text { - Espírito de } \\
\text { equipe; } \\
\text { - Vontade de } \\
\text { vencer junto; } \\
\text { - Tolerância } \\
\text { com o ego do } \\
\text { outro; } \\
\text { - Foco no } \\
\text { objetivo; } \\
\text { - Ter pulso } \\
\text { firme; } \\
\text { - Perseverança; } \\
\text { - Tolerância em } \\
\text { geral. }\end{array}$ & $\begin{array}{l}\text { - Profissionais } \\
\text { constantemente } \\
\text { - atualizados; } \\
\text { - Aprendizado } \\
\text { constante; } \\
\text { - Pré-disposição a } \\
\text { - } \text { aprender; } \\
\text { - Luriosos; } \\
\text { - Leitores; } \\
\text { - Estar atento ao que se } \\
\text { passa ao redor; } \\
\text { - Disposição de bem } \\
\text { conviver; } \\
\text { - Ter valores; } \\
\text { - Espírito de união; } \\
\text { - Ser disponível; } \\
\text { - Colaboração; } \\
\text { - Saber ouvir; } \\
\text { - Manter o clima } \\
\text { harmônico. }\end{array}$ & $\begin{array}{l}\text { - Conhecimen } \\
\text {-to técnico; } \\
\text { - Facilidade } \\
\text { de } \\
\text { relaciona- } \\
\text { mento; } \\
\text { - Inteligência } \\
\text { emocional; } \\
\text { - Bom senso. }\end{array}$ & $\begin{array}{l}\text { - Cooperação e } \\
\text { colaboração; } \\
\text { - Amizade; } \\
\text { - Profissionalis- } \\
\text { mo; } \\
\text { - Ética; } \\
\text { - Reciclagem. }\end{array}$ \\
\hline
\end{tabular}

Figura 9: Competências, Habilidades e Atitudes Essenciais para a Equipe. Fonte: Elaborado pelas autoras.

Ressalta-se que os bibliotecários diretores/gestores pesquisados mencionaram que as principais necessidades de formação e de atualização profissional da equipe, uma vez que acreditam na importância da educação continuada para a melhoria da atuação da equipe, abarca desde o aprimoramento do conhecimento técnico para desenvolverem atividades especializadas, até o aprimoramento de competências, habilidades e atitudes que permitam um melhor atendimento aos usuários, afinal segundo eles, o desenvolvimento das competências, habilidades e atitudes, sejam técnicas ou não visam sempre o usuário final.

Além disso, os diretores/gestores pesquisados entendem a falta da educação continuada como um fator determinante para a desmotivação da equipe. Dois bibliotecários diretores/gestores pesquisados, atuantes nas unidades de informação privadas, acreditam ser este um fator de desmotivação, visto que não há incentivo ou política da própria instituição para os funcionários se atualizarem. Os bibliotecários diretores/gestores pesquisados, atuantes nas unidades de informação públicas, mostraram-se positivos, no que diz respeito à educação continuada, contudo ressaltaram que essas instituições têm um orçamento muito pequeno, ou seja, nem sempre é possível destinar verbas para essa demanda/necessidade funcional. Nesse caso, os dois sujeitos destacaram que buscam recursos externos à instituição, visando a propiciar essa capacitação de forma que a equipe se sinta capaz, útil, valorizada, porquanto é um fator motivacional para o trabalho.

O bibliotecário diretor/gestor da 'Unidade de Informação B' acredita que "a questão da desmotivação é muito mais complexa [...] [e] não é necessariamente salário, infra-estrutura ou a falta dela, não é necessariamente a falta de capacitação [...] são condições intrínsecas à própria pessoa [...] isso é usado como desculpa".

As pessoas desmotivadas, muitas vezes, verbalizam que nada acontece, mas elas mesmas não aceitam as possibilidades de mudança, seja por meio da capacitação, seja por meio da mudança da infra-estrutura. Por outro lado, também, existem pessoas que já possuem um ambiente de trabalho adequado, infra-estrutura tecnológica adequada, assim como condições e incentivo para a educação continuada, mas, mesmo assim, não se sentem motivadas, ou seja, são desmotivadas com elas mesmas ou com a vida profissional. 
A motivação de equipes está relacionada à interação, como já foi mencionado anteriormente, dessa forma, buscouse saber se os bibliotecários diretores/gestores das unidades de informação pesquisadas promoviam reuniões periódicas com as suas equipes. Todos os bibliotecários pesquisados têm consciência e reconhecem o quanto é importante à comunicação com a equipe, para transmitir informações, esclarecer dúvidas, resolver problemas (atividades ou de relacionamento entre as pessoas), manifestar interesses etc.

Um dos bibliotecários diretores/gestores pesquisados informou que, na medida do possível, realizava reuniões periodicamente, mas devido aos resultados da reunião não serem satisfatórios, passou a realizar reuniões pontuais e somente quando necessário. Contudo, ressaltou que o fato de não haver reuniões periódicas, não prejudica a transmissão das informações para e entre os membros da equipe. Explicou que a comunicação não é formal, visto que as informações são disseminadas pelos corredores, no café, por e-mail etc., com o objetivo de não haver problemas com a desinformação. Quando há um assunto emergencial a ser tratado com toda a equipe, realiza-se uma reunião formal.

A promoção ou não de reuniões periódicas, está relacionada ao estilo de dirigir/gerenciar e, certamente, tem a haver com o perfil de cada bibliotecário diretor/gestor. Destaca-se que as reuniões são fundamentais para o trabalho em equipe, pois é nesse momento que o conhecimento pode ser compartilhado da melhor forma, bem como propicia mais segurança aos membros da equipe, visto que todas as questões são discutidas até se tornarem claras.

Buscou-se saber de que forma os bibliotecários diretores/gestores motivam a equipe que dirigem/gerenciam. Para isso, foi solicitado aos sujeitos pesquisados citarem três ações que utilizam para motivarem a equipe:

\begin{tabular}{|c|c|c|c|c|}
\hline $\begin{array}{l}\text { Sujeitos } \\
\text { Pesquisados }\end{array}$ & $\begin{array}{c}\text { Unidade de } \\
\text { Informação } \\
\text { A }\end{array}$ & $\begin{array}{c}\text { Unidade de } \\
\text { Informação } \\
\text { B }\end{array}$ & $\begin{array}{c}\text { Unidade de } \\
\text { Informação } \\
\text { C }\end{array}$ & $\begin{array}{c}\text { Unidade de } \\
\text { Informação } \\
\text { D }\end{array}$ \\
\hline $\begin{array}{l}\text { Exemplos / } \\
\text { Ações }\end{array}$ & $\begin{array}{l}\text { - Incentivo à } \\
\text { leitura de } \\
\text { textos e } \\
\text { notícias da } \\
\text { área; } \\
\text { - Propor } \\
\text { novos } \\
\text { desafios; } \\
\text { - Atitude } \\
\text { flexível, para } \\
\text { favorecer o } \\
\text { bem estar } \\
\text { das } \\
\text { pessoas. }\end{array}$ & $\begin{array}{l}\text { - Capacitação } \\
\text { profissional; } \\
\text { - Informalidade; } \\
\text { - Boa infra- } \\
\text { estrutura; } \\
\text { - Relação } \\
\text { saudável; } \\
\text { - Ambiente de } \\
\text { trabalho } \\
\text { saudável; } \\
\text { - Temperamento } \\
\text { firme; } \\
\text { - Preocupação com } \\
\text { o bem estar do } \\
\text { funcionário; } \\
\text { - Ser flexível para } \\
\text { dialogar; } \\
\text { - O que eu quero } \\
\text { de bom para mim, } \\
\text { eu também quero } \\
\text { para a equipe. }\end{array}$ & $\begin{array}{l}\text { - Plano de } \\
\text { metas com } \\
\text { recompensa } \\
\text { salarial; } \\
\text { - Plano de } \\
\text { cargo e } \\
\text { salários } \\
\text { contendo um } \\
\text { plano de } \\
\text { promoção por } \\
\text { merecimento; } \\
\text { - Treinamentos } \\
\text { periódicos da } \\
\text { equipe. }\end{array}$ & $\begin{array}{l}\text { - Incentivo para a } \\
\text { participação em } \\
\text { cursos, eventos; } \\
\text { - Incentivo para a } \\
\text { publicação de textos; } \\
\text { - Em termos de } \\
\text { serviço, por em } \\
\text { prática as idéias } \\
\text { sugeridas por eles; } \\
\text { - Explorar habilidades e } \\
\text { idéias que o } \\
\text { funcionário tem de } \\
\text { melhor; } \\
\text { - Avaliação } \\
\text { profissional; } \\
\text { - Reconhecimento, } \\
\text { elogios do púbico } \\
\text { interno e externo; } \\
\text { - Happy hour fora do } \\
\text { ambiente de trabalho. }\end{array}$ \\
\hline
\end{tabular}

Figura 10: Ações para Motivar a Equipe.

Fonte: Elaborado pelas autoras. 
O bibliotecário diretor/gestor da 'Unidade de Informação C' indaga por que alguns autores que estudam sobre esse assunto, não defendem a recompensa salarial como uma forma de motivar, porquanto argumentam que nem sempre o dinheiro é um fator motivacional. Contudo, o bibliotecário entrevistado acredita na recompensa salarial como um fator de motivação.

Perguntados se acreditavam que as ações mencionadas para motivar a equipe de fato atingiam esse objetivo, qual seja, o de motivar a equipe liderada por eles, os bibliotecários diretores/gestores mencionaram consensualmente que procuram manter o ambiente harmônico em relação ao trabalho, buscando o equilíbrio para, no mínimo, conseguir que as pessoas não se sintam desmotivadas.

\begin{tabular}{|l|c|c|c|c|}
\hline $\begin{array}{l}\text { Sujeitos } \\
\text { Pesquisados }\end{array}$ & $\begin{array}{c}\text { Unidade de } \\
\text { Informação } \\
\text { A }\end{array}$ & $\begin{array}{c}\text { Unidade de } \\
\text { Informação }\end{array}$ & $\begin{array}{c}\text { Unidade de } \\
\text { Informação } \\
\text { B }\end{array}$ & $\begin{array}{c}\text { Unidade de } \\
\text { Informação }\end{array}$ \\
\hline $\begin{array}{l}\text { Consegue Manter } \\
\text { a Equipe Motivada }\end{array}$ & $\begin{array}{l}\text { - Consigo manter } \\
\text { o equilíbrio, mas } \\
\text { não motivar. }\end{array}$ & $\begin{array}{l}\text { - Acho que não } \\
\text { são } \\
\text { desmotivados. }\end{array}$ & - Consigo. & $\begin{array}{l}\text { - Na medida do } \\
\text { possível } \\
\text { consigo, mas } \\
\text { tenho muitas } \\
\text { falhas. }\end{array}$ \\
\hline
\end{tabular}

Figura 11: Manutenção da Equipe Motivada. Fonte: Elaborado pelas autoras.

Quando o bibliotecário diretor/gestor da 'Unidade de Informação D' respondia essa questão, mencionou algumas competências, habilidades ou ações que auxiliam na motivação da equipe:

- $\quad$ "Buscar melhorias para o ambiente, bem como palestras e cursos;

- Conversar bastante visando maior aproximação com o funcionário, pois os funcionários gostam de dialogar, até mesmo pra falar de problemas pessoais;

- Respeitar os diferentes comportamentos e modos de agir;

- $\quad$ Chamar atenção, mas nunca de forma agressiva, quando necessário;

- Aceitar críticas dos funcionários, quando visam à melhoria das atividades e do ambiente;

- Não ter ou tomar atitudes isoladas e precipitadas".

Observou-se de forma recorrente que a expressão 'cobrança de resultados' faz parte da função desses bibliotecários diretores/gestores, até mesmo pelo cargo/função exercido por eles, porquanto eles, também, são cobrados pela hierarquia superior da organização na qual atuam.

Um dos fatores de motivação, abordado na literatura, é o empenho da organização em relação ao incentivo e apoio na execução das atividades/tarefas. No entanto, o bibliotecário diretor/gestor da 'Unidade de Informação A' destacou que há a falta de contribuição e apoio, em algumas questões, por parte da organização em que atua.

No que tange aos elementos motivacionais, infere-se que as ações mencionadas pelos profissionais entrevistados podem ser muito relevantes para a motivação de equipes. Além disso, essas ações se equiparam àquelas encontradas na literatura. 


\section{Considerações finais}

Constatou-se com a pesquisa que realmente os bibliotecários diretores/gestores pesquisados pouco conhecem sobre as teorias motivacionais, e as ações realizadas por eles visando a motivação da equipe, são baseadas em experiências profissionais anteriores, na prática de seus pares e, também, nas situações cotidianas vivenciadas. Destaca-se, que a prática profissional analisada por meio das entrevistas não é tão distante da encontrada na literatura, contudo muitas ações poderiam ser melhoradas a partir de um maior conhecimento sobre essas questões, por parte dos diretores/gestores de unidades de informação.

Em relação à motivação, percebe-se que não basta só o líder querer motivar a sua equipe, visto que é uma questão mais complexa do que se imagina, pois cada pessoa tem seus próprios interesses, objetivos e orientações motivacionais.

Como encontrado na literatura e conforme constatado na realidade profissional dos bibliotecários pesquisados, os diretores/gestores possuem algumas competências, habilidades e atitudes que podem auxiliá-los a gerenciar suas equipes e conduzi-las em busca de resultados e metas planejadas para a unidade de informação como, por exemplo, manter-se informado, incentivado e comprometido com os objetivos, comunicar-se bem, amenizar situações conflitantes e manter o ambiente harmônico, conseqüentemente, obter da equipe o seu melhor desempenho, favorecendo assim, a motivação.

Para melhor visualização e clareza do que foi exposto acima, a seguir, apresentar-se-á uma comparação entre o identificado na literatura e o identificado na prática profissional.

\begin{tabular}{|c|c|}
\hline Literatura & Prática Profissional \\
\hline $\begin{array}{l}\text { Competências: saber organizar; saber antecipar-se; } \\
\text { saber analisar uma situação; ser rigoroso; saber realizar } \\
\text { uma síntese; resumo; saber ouvir; saber precisar; saber } \\
\text { ser disponível; saber negociar; saber adaptar-se; saber } \\
\text { ensinar; saber trabalhar em equipe; saber autoformar-se; } \\
\text { saber conduzir uma equipe; ter espírito crítico; ser } \\
\text { autônomo; saber motivar-se; saber avaliar-se. }\end{array}$ & $\begin{array}{l}\text { - Comunicação; } \\
\text { - Bom senso; } \\
\text { - Bom humor; } \\
\text { - Curiosos; } \\
\text { - Leitores; } \\
\text { - Ter valores; } \\
\text { - Ser disponível; } \\
\text { - Saber ouvir; }\end{array}$ \\
\hline $\begin{array}{l}\text { Competências Comportamentais: Visão Sistêmica; } \\
\text { Orientação a resultados; Conhecimento; Capacidade } \\
\text { empreendedora; Liderança; Comunicação; Foco no } \\
\text { cliente/funcionário; Trabalho em equipe; Negociação; } \\
\text { compromisso com a excelência da prestação de serviço } \\
\text { (ser um profissional); Procurar desafios e oportunidades } \\
\text { de crescimento dentro e fora das unidades de } \\
\text { informação; ver o conjunto das situações; buscar } \\
\text { alianças e parcerias; possuir habilidades de } \\
\text { comunicação; ser líder; ser flexível e positivo em uma } \\
\text { época de mudanças contínua. }\end{array}$ & $\begin{array}{l}\text { - Etica; } \\
\text { - Reputação; } \\
\text { - Ter pulso firme; } \\
\text { - Perseverança; } \\
\text { - Paciência / Não tomar atitudes } \\
\text { - Tocipitadas; } \\
\text { - Tolerância; } \\
\text { - Facilidade de relacionamento; } \\
\text { - Amizade; } \\
\text { - Disposição de bem conviver; } \\
\text { - Inteligência emocional; } \\
\text { - Dar exemplo de comportamento; }\end{array}$ \\
\hline $\begin{array}{l}\text { Habilidades: conhecer a cultura organizacional das } \\
\text { organizações; ambição profissional; identificar } \\
\text { oportunidades; apreciar desafios; iniciativa; } \\
\text { assertividade; postura inovadora; atuar como mentor e } \\
\text { orientador; intuição; compartilhar informações; } \\
\text { julgamento; estratégia; liderança; conhecer o conteúdo } \\
\text { dos recursos informacionais; elaborar e implantar } \\
\text { soluções de problemas; criatividade; motivação; dar } \\
\text { suporte às tomadas de decisões; espírito jovem; } \\
\text { desenvolver relacionamentos; persuasão; dinamismo; }\end{array}$ & $\begin{array}{l}\text { - Manter clima e o ambiente } \\
\text { - Asarmônico; } \\
\text { - Confiança; } \\
\text { - Passar segurança para a equipe; } \\
\text { - Compartilhar vitórias; } \\
\text { - Saber trabalhar em equipe; } \\
\text { - Espírito de equipe; } \\
\text { - Espírito de união; } \\
\text { - Vontade de vencer junto; }\end{array}$ \\
\hline
\end{tabular}




\begin{tabular}{|l|l|}
\hline pós-graduação; disciplina; postura pró-ativa; maturidade & - Pré-disposição das pessoas para \\
emocional; predisposto à mudança; espírito & cumprir o que foi combinado; \\
empreendedor; receptividade; estar envolvido com o & - Tato (para discernir o que acontece \\
cargo; relacionamento interpessoal; ética profissional; & ao redor); \\
senso de responsabilidade/senso de compromisso; uso & - Ser um profissional dedicado; \\
eficiente das tecnologias; ser comunicativo; flexibilidade; & - Profissionalismo; \\
ser detalhista; generalista; simplificar estruturas; & - Engajamento; \\
consultiva; trabalhar com informações; gerenciamento; & - Comprometimento; \\
trabalhar em equipe; negociação; versatilidade; & - Colaboração; \\
relacionamento; construção de uma rede de contatos; & - Cooperação; \\
treinamento; resolução de conflitos; tolerância; & - Objetividade; \\
processamento de informações; construir redes & - Foco no objetivo; \\
informais; capacidade de decidir; alocação de recursos; & - Profissionais constantemente \\
definição de prioridades; de introspecção; capacidade de de & atualizados; \\
reflexão e auto-análise; aprender com a própria & - Aprendizado constante; \\
experiência; técnica; planejamento; raciocínio abstrato. & - Pré-disposição a aprender; \\
\hline $\begin{array}{l}\text { Atitudes: arrojada; eficaz; decidida (pró-ativa); } \\
\text { diplomática; coerente; racional; transparente; espírito }\end{array}$ & - Reciclagem; \\
associativo; criatividade; rigor e precisão; senso crítico; & - Visanoral do trabalho (todos os \\
sábia; adaptável; organizada; responsável; cooperativa; & - Visão geral de todo o conjunto; \\
altruísta; solidária; tolerante; receptiva; pragmática; & - Conhecimento técnico. \\
moldável; otimista; sensata; flexível; capacidade de & \\
trabalhar em equaipe; respeito à ética e aos aspectos & \\
legais da profissão; sensibilidade para a necessidade & \\
informacional de usuários reais e potenciais; & \\
profissionais; curiosidade intelectual e postura & \\
investigativa para continuar aprendendo. & \\
\hline
\end{tabular}

Figura 12: Competências, Habilidades e Atitudes - Literatura x Prática Profissional. Fonte: Elaborado pelas autoras.

No que concerne à formação/capacitação/educação continuada percebe-se que é dada grande importância à atualização profissional, mais especificamente no que diz respeito ao comportamento humano, notou-se que a maior parte desse conhecimento é proveniente da prática diária e, em alguns casos, também, através, da leitura de textos.

Sobre a educação continuada, a especialização foi uma das principais necessidades de formação identificada pelos bibliotecários diretores/gestores entrevistados, pois como bem explicou o bibliotecário da 'Unidade de Informação A', a atualização continuada é fundamental para que o "processo criativo não adormeça e nem fique atrofiado".

Não se identificou nenhuma diferença significativa no que tange à formação dos bibliotecários diretores/gestores pesquisados, mesmo a graduação de alguns deles ter sido realizada no interior e de outros na capital do Estado de São Paulo.

No que diz respeito às ações do líder para motivar a equipe, acredita-se que os bibliotecários diretores/gestores pesquisados conseguem tal êxito. Segue abaixo uma comparação entre as ações encontradas na literatura e as mencionadas pelos entrevistados.

\begin{tabular}{|l|l|}
\hline Literatura & Prática Profissional \\
\hline - Colaboração e interdependência; & - Capacitação profissional; \\
- Envolvimento emocional; & - Treinamentos periódicos da \\
- Respeito; & equipe; \\
- Empenho da organização; & - Incentivo na participação de \\
- Cursos, eventos, atualização e na \\
- Liderar; & publicação de documentos; \\
- Implantar programas participativos; & - Incentivo à leitura de textos e \\
- Estabelecer metas desafiadoras; & notícias da área; \\
\hline
\end{tabular}


- Incentivar trabalhos em grupo;

- Camaradagem;

- Estimular o sentido de comunidade;

- Promover reuniões da organização/unidade ou área;

- Implantar reuniões diárias (falar / ouvir);

- Promover eventos comemorativos no setor;

- Criar sistemas de divulgação de resultados;

- Criar sistemas de informação, visando uma melhor comunicação entre os setores;

- Promover rotação de cargos e funções;

- Estimular a criatividade;

- Promover confraternização externa à empresa;

- Promover visitas em outros setores, unidades e organizações;

- Promover um bom ambiente de trabalho;

- Promover educação e treinamento;

- Incentivar o autodesenvolvimento;

- Crescimento pessoal e em equipe;

- Definir claramente as responsabilidades de cada membro da equipe;

- Definir claramente o propósito claro e comum;

- Elaborar normas claras e coerentes;

- Delegar autoridade conscientemente;

- Responsabilidade;

- Empowerment;

- Implantar avaliação de desempenho;

- Cobrar resultados;

- Implantar sistemas de reconhecimento por metas atingidas;

- Justiça e valorização;

- Implantar o kanban emocional;

- Gerenciar a "moral" da equipe;

- Promover os elementos com melhor desempenho / habilidade;

- Dar aos empregados às informações necessárias para a realização do trabalho;

- Dar feed-back regular aos funcionários;

- Solicitar idéias e envolvê-los em decisões sobre suas funções;

- Aprender com os próprios funcionários sobre aquilo que os motiva;

- Reconhecer as necessidades pessoais dos funcionários;

- Permitir, na medida do possível, ao funcionário fazer o que gosta;

- Dar aos empregados uma tarefa interessante para executar;

- Verificar se o empregado dispõe das ferramentas necessárias para realizar o melhor trabalho;

- Desempenho como base para promoção;

- Adotar uma política abrangente de promoção dos funcionários;

- Remunerar as pessoas de forma competitiva.
- Propor novos desafios;

- Relação saudável;

- Temperamento firme;

- Atitude flexível, para favorecer o bem estar das pessoas;

- Preocupação com o bem estar do funcionário;

- Atitude altruísta;

- Ser flexível para dialogar;

- Informalidade;

- Boa infra-estrutura;

- Ambiente de trabalho saudável;

- Plano de metas com recompensa salarial;

- Plano de cargo e salários contendo possibilidade de promoção por merecimento;

- Cobrar resultados;

- Em termos de produtos e serviços, por em prática as idéias sugeridas por eles;

- Explorar habilidades e idéias que o funcionário tem de melhor;

- Avaliação Profissional;

- Reconhecimento;

- Elogios do púbico interno e externo;

- Confraternização interna;

- Happy hour fora do ambiente de trabalho.

Figura 13: Ações Motivacionais - Literatura x Prática Profissional. Fonte: Elaborado pelas autoras. 
Espera-se que esta pesquisa possa contribuir para os profissionais da informação que atuam como diretores/gestores ou líderes de unidades de informação, de forma que possam motivar ou ao menos manter um clima voltado à aprendizagem de suas equipes, bem como propiciar condições de melhoria para o desempenho de seus colaboradores para a execução das atividades/tarefas, melhorar o relacionamento e o espírito de equipe, além de manter um ambiente de trabalho harmonioso.

Para que as equipes bibliotecárias possam desempenhar satisfatoriamente suas atividades/tarefas é essencial que haja um diretor/gestor e/ou líder que atue como um elemento integrador, e que saiba conduzir a equipe gerenciando bem a diversidade. Dessa maneira, entende-se que o líder precisa conhecer bem sua equipe e os valores que a regem, assim como precisa conhecer os fatores que propiciam a motivação. Para tanto, deve interagir com seus colaboradores observando suas necessidades, objetivando verificar se a organização tem sido capaz de satisfazêlas.

Os diretores/gestores e/ou líderes devem ser conscientes que em relação a agregar valor significativo à unidade de informação e obter resultados satisfatórios, dependerá de seu comportamento, suas atitudes, postura e capacidade de influenciar a equipe.

Acredita-se que a presença do líder é fundamental em qualquer tipo de unidade de informação. Sem dúvida alguma, os profissionais da informação que atuam como diretores/gestores de equipes devem assimilar e ser conscientes da importância do seu papel, uma vez que este é o primeiro passo para obter um ambiente harmônico.

\section{Referências}

BERGAMINI, C. W. Motivação. 3.ed. São Paulo: Atlas, 1991. 139p.

BERGAMINI, C. W. Motivação: mitos, crenças e mal-entendidos. In: Revista de Administração de Empresas - RAE/FGV, São Paulo, v.30, n.2, p.23-34, abr./jun. 1990

BERTO, R. M. V. S.; PLONSKI, G. A. Gestão do conhecimento e as novas competências dos profissionais da informação. In: WORKSHOP BRASILEIRO DE INTELIGÊNCIA COMPETITIVA E A GESTÃO DO CONHECIMENTO, 1., Rio de Janeiro. Anais... Rio de Janeiro. 1999. v.1; 1CD-ROM

CARDOZO, C. M. O trabalho em equipe e seus motivadores. São Paulo: EAESP/FGV, 2003. 63f. Dissertação (Mestrado Profissional em Administração) - Escola de Administração de Empresas de São Paulo, Fundação Getúlio Vargas, São Paulo.

CAUDRON, S. O que motiva os empregados: cure a ressaca da reengenharia. In: HSM Managemet, São Paulo, n.1, mar./abr. 1997.

CHIAVENATO, I. Introdução à Teoria Geral da Administração. 6.ed. São Paulo: Campus, 2000, 700p.

CONSELHO DA JUSTIÇA FEDERAL. Gestão de pessoas por competências. Disponível em: <http://www.conline1.cjf.gov.br/phpdoc/pages/sen/gestao/index.asp>. Acesso em: 28 jun. 2006;

DIAS, R. N.; DIAS, S. N. Motivação no setor público. Disponível em: <www.ulbra.br/santamaria/posmedio/downloads/Motiva\%E7\%E30\%20SetorP\%FAblico.pdf >. Acesso em: 28 jun. 2006.

EASTON, S. Team analysis. Center for the study of work teams. Newsletter, v.3, n.3, 1993. Disponível em: <http://www.workteams.unt.edu/newsletter>. Acesso em: 24 jul. 2002.

FELLIPE, M. I. Motivação e trabalho em equipe podem fazer a diferença. Disponível em: <http://www.sprinter.com.br/index.php? Itemid=34\&id=25\&option=com_content\&task=view>. Acesso em: 01 jun. 2009.

GOOCH, B. G.; MCDOWELL, P. J. Use anxiety to motivate. Personnel Journal, USA, p.5, Apr. 1988.

HOECKELE, L. C. O que motiva uma equipe? Disponível em: $<$ http://www.varejista.com.br/novo site/desc materia.asp?id=1819>. Acesso em: 28 jun. 2006.

KATZENBACH, J. R.; SMITH, D. K. The discipline of teams. Harvard Business Review, p.111-120, Mar./Apr. 1993.

LANE, S. T. M. O processo grupal. In: LANE, S. T. M.; CODO, W. Psicologia social: o homem em movimento. São Paulo: Brasiliense, 1984. 
MARCHIORI, P. Z. Que profissional queremos formar para o século XXI - graduação. Informação\&Informação, Londrina, v.1, n.1, p.27-34, jan./jun. 1996.

MARX, R. Trabalhos em grupo e autonomia como instrumentos de competição: experiência internacional, casos brasileiros, metodologia da implantação. São Paulo: Atlas, 1997.

MAXIMIANO, A. C. A. Introdução à Administração. 6.ed. São Paulo: Atlas, 2004. 434p.

MAXIMIANO, A. C. A. Introdução à Administração. 5.ed. São Paulo: Atlas, 2000b. 546p.

MAXIMIANO, A. C. A. Teoria Geral da Administração: da escola clássica à competitividade na economia globalizada. 2.ed. São Paulo: Atlas, 2000a. 530p.

MAXIMIANO, A. C. A. Teoria Geral da Administração: da revolução urbana à revolução digital. 3.ed. São Paulo: Atlas, 2002. $521 \mathrm{p}$.

MEGGINSON, L. C. ; MOSLEY, D. C. ; PIETRI JR., P. H. Administração: conceitos e aplicações. 4.ed. São Paulo: Harbra, 1998. $614 p$.

MINTZBERG, H. O trabalho do executivo: o folclore e o fato. São Paulo: Abril, 1986.

MOREIRO GONZALES, J. A.; TEJADA, C. Competencias profesionales en el área de la Ciencia de la Información. In: VALENTIM, M. L. P. (Org.). Atuação profissional na área de informação. São Paulo, 2004. 191p.; p.97-110 (Coleção Palavra-Chave, 14)

NEVES, E. C. Profissional da informação: habilidades e competências na era do conhecimento. Campinas: PUC-Campinas, 2002. 125f. Dissertação (Mestrado em Biblioteconomia e Ciência da Informação). - Faculdade de Biblioteconomia, Pontifícia Universidade Católica, Campinas.

NONAKA, I. A empresa criadora de conhecimento. In: Gestão do conhecimento. Rio de Janeiro: Campus, 2000. p.27-29

PONJUÁN DANTE, G. Perfil del profesional de información del nuevo milenio. In: VALENTIM, M. L. P. (Org.). O profissional da informação: formação, perfil e atuação profissional. São Paulo: Polis, 2000. 156p.; p.91-105 (Coleção Palavra-Chave, 11)

RESOLUCIÓN de Tokyo sobre una alianza estratégica de las organizaciones internacionales no gubernamentales en información para servir mejor a la comunidad mundial. FID News Bulletin, The Hague, v.44, n.12, p.313-315, 1994.

SANTOS, J. P. O perfil do profissional bibliotecário. In: VALENTIM, M. L. P. (Org.) O profissional da informação: formação, perfil e atuação profissional. São Paulo: Polis, 2000. 156p.; p.107-117 (Coleção Palavra-Chave, 11)

TACHIZAWA, T.; FERREIRA, V. C. P.; FORTUNA, A. A. M. Gestão com pessoas: uma abordagem aplicada às estratégias de negócios. Rio de Janeiro: FGV, 2001. 260p.

VALENTIM, M. L. P. (Org.). O profissional da informação: formação, perfil e atuação profissional. São Paulo: Polis, 2000. 156p. (Coleção Palavra-Chave, 11)

VALENTIM, M. L. P. Formação: competências e habilidades do profissional da informação. In: profissional da informação. São Paulo: Polis, 2002. 152p.; p.117-132 (Coleção Palavra-Chave, 13)

(Org.). Formação do 


\section{Dados das autoras}

\section{Vanessa Lima dos Santos}

Bacharel em Biblioteconomia pela Universidade Estadual Paulista - UNESP. Câmpus de Marília

vanessa.sanntos@gmail.com

Daniela Pereira dos Reis de Almeida

Doutora em Ciência da Informação. Professora do Departamento de Ciência da Informação da Faculdade de Filosofia e Ciências da Universidade Estadual Paulista - UNESP.

danireis@marilia.unesp.br

\section{Marta Lígia Pomim Valentim}

Livre docente em Informação, Conhecimento e Inteligência Organizacional.Doutora em Ciências da Comunicação.

Professora do Departamento de Ciência da Informação e do Programa de Pós-Graduação em Ciência da Informação da Universidade Estadual Paulista - UNESP.

valentim@valentim.pro.br

Recibido - Received: 2011-04-05

Aceptado - Accepted: 2012-03-31

\section{(c) EY-NC-ND}

This work is licensed under a Creative Commons

Attribution-Noncommercial-No Derivative Works 3.0 United States License.

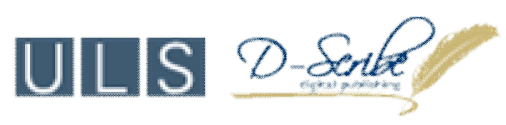

This journal is published by the University Library System of the University of Pittsburgh as part of its D-Scribe Digital Publishing Program and is cosponsored by the University of Pittsburgh Press. 